\title{
Paleogene calcareous nannofossil biostratigraphy for two boreholes in the eastern Austral Basin, Patagonia, Argentina
}

\author{
Juan Pablo Pérez Panera
}

CONICET- División Paleozoología Invertebrados, Museo de La Plata, Paseo del Bosque s/n, B1900FWA, La Plata, Argentina. perezpanera@gmail.com

\begin{abstract}
Calcareous nannofossils from two boreholes (Campo Bola and Sur Río Chico) in the subsurface of eastern Austral Basin, Santa Cruz Province, Argentina, allowed the identification of Early to Middle Paleocene, Early to Middle Eocene and Late Eocene to Early Oligocene assemblages. These assemblages match the formations logged in the boreholes Campo Bola, Man Aike and Río Leona respectively, and represent three paleogene sedimentary cycles within the basin. These results permitted the reinterpretation of previous data from an adjacent borehole (Cerro Redondo). The southern boreholes (Cerro Redondo and Sur Río Chico) yield an Early to Middle Paleocene calcareous nannofossil assemblage and an almost continuous record of nannofossils from Early Eocene to Early Oligocene. A discontinuity is interpreted by the absence of Late Paleocene assemblages. The northern borehole (Campo Bola) yield only late Early Eocene to Early Oligocene assemblages. The data also indicates that the Paleogene beds unconformably overlie Upper Cretaceous strata.
\end{abstract}

Keywords: Calcareous nannofossils, Cenozoic, Biostratigraphy, Argentina.

RESUMEN. Nanofósiles calcáreos paleógenos y biostratigrafía para dos pozos en el este de la Cuenca Austral, Patagonia, Argentina. El estudio de los nanofósiles calcáreos recuperados en muestras de subsuelo de dos pozos de exploración (Campo Bola y Sur Río Chico) en el este de la Cuenca Austral, provincia de Santa Cruz, Argentina, permitió reconocer asociaciones del Paleoceno Temprano a Medio, Eoceno Temprano a Medio y Eoceno Tardío a Oligoceno Temprano. Estas asociaciones son coincidentes con las formaciones atravesadas en los sondeos hechos en Campo Bola, Man Aike y Río Leona, respectivamente, y representan tres ciclos sedimentarios paleógenos dentro de la cuenca. Estos resultados permitieron la reinterpretación de datos previos de un pozo adyacente (Cerro Redondo). Los pozos ubicados al sur (Cerro Redondo y Sur Río Chico) contienen asociaciones de nanofósiles calcáreos del Paleoceno Temprano a Medio y un registro prácticamente continuo de nanofósiles del Eoceno Temprano al Oligoceno Temprano. Se interpreta una discontinuidad por ausencia de asociaciones del Paleoceno Tardío. El pozo ubicado más al norte (Campo Bola) contiene solo asociaciones del Eoceno Temprano tardío al Oligoceno Temprano. Los datos también indican que las capas paleógenas sobreyacen en disconformidad a estratos del Cretácico Superior. 


\section{Introduction}

The Austral Basin is located in southern South America and spans part of Patagonia and the Argentinean Continental Platform, including Isla Tierra del Fuego (Nullo et al., 1999; Malumián, 1999). The sedimentary infill started in the Late Jurassic, and ended in the Neogene. The Paleogene consists of four major sedimentary cycles, a succession of marine and continental deposits with clear facies differences in different parts of the basin (Malumián, 1999, 2002; Olivero and Malumián, 2008). This makes correlation between the different sectors difficult, but integrated biostratigraphic studies can elucidate the history and evolution of the basin. The deepest paleodepths are found in the southeastern sector, mainly around Isla Tierra del Fuego and the Argentinean Continental Platform, whereas the central and western parts of the basin represent shallow-marine to continental environments. This basin is of petroleum interest, and biostratigraphical studies have been of primary importance. The microfossils of the Paleogene succession, particularly foraminifers (synthesis by Malumián and Náñez, 1996, 2002), have long been studied and have proved to be highly useful on age and paleoenvironmental interpretation.

The purpose of this study is to provide independent biostratigraphic and paleoceanographic information on the calcareous nannofossil assemblages in the eastern Austral Basin to complement that already known from the foraminifers. The studied Paleogene succession is from two boreholes (Sur Río Chico and Campo Bola) in the eastern coastal margin of the basin (Fig. 1), that crossed the Campo Bola, Man Aike and Río Leona formations (Fig. 2, Table 1). Those boreholes are close to the previously studied Cerro Redondo borehole (Pérez Panera, 2009), which is reinterpreted at the light of these new results. The underlying Cretaceous sequence is discussed in Pérez Panera (2012).

\section{Geological framework}

The history of the Austral Basin can be divided in three main phases (Biddle et al., 1986; Robbiano et al., 1996; Nullo et al., 1999; Ramos, 2002; Rodríguez and Miller, 2005). The first one occurred during the Triassic-Middle to Late Jurassic, with the extensional tectonics that fragmented Gondwana and produced the early opening of the South Atlantic
Ocean (Peroni et al., 2002). This rifting phase was dominated by grabens, halfgrabens and acid volcanism. This volcanic episode ceased by the Late Jurassic to Early Cretaceous and was succeeded by a sag-phase characterized by thick marine sedimentary deposits. In the late Early Cretaceous, the Patagonidic Movements produced an uplift of the crust in the western part of the basin that started the development of a foreland basin to the east (Nullo et al., 1999). This produced an eastward migration of continental sediments due to the shifting of the depocenter of the basin from west to southeast.

With the uplift of the Andes during the Paleogene, the sedimentation in the basin became more continental in nature with clear differences between the western and the eastern part, where there was still some marine influence. Table 1 summarizes the boundaries, relationships, and equivalences of the different Paleogene formations across the Austral Basin. The sedimentation during this time can be divided into four sedimentary cycles related to marine incursions, mainly from the Atlantic Ocean (Malumián, 1999, 2002; Malumián and Náñez, 2002; Malumián and Jannou, 2010; Olivero and Malumián, 2008). In the boreholes studied herein, only the older three Paleogene sedimentary cycles were identified which are described below:

\subsection{First sedimentary cycle (Late Maastrichtian- Early Eocene)}

The first sedimentary cycle started during the Late Maastrichtian and ended in the Early Eocene. During this cycle, the continental sandstones of the Calafate Formation that crop out in the proximity of Lago Argentino, are considered to be of Paleocene age whereas, south from Lago Argentino, the Calafate Formation is a shallow-marine facies of Late Maastrichtian age (Malumián and Caramés, 1997). Marenssi et al. (2004) also assigned a Maastrichtian age for these rocks, based on the presence of the megaspore Grapnelispora loncochensis Papú, 1997 as did Guerstein et al. (2005) on the basis of the dinocyst Diconodinium lurense Guerstein et al., 2005. The Danian is represented by transgressive units in the Río Turbio area and by condensed sequences in the subsurface of eastern Santa Cruz Province (Malumián et al., 1971; Malumián and Caramés, 1995, 1997). These sequences are Cerro Dorotea and Campo Bola formations, respectively. The sediments are 


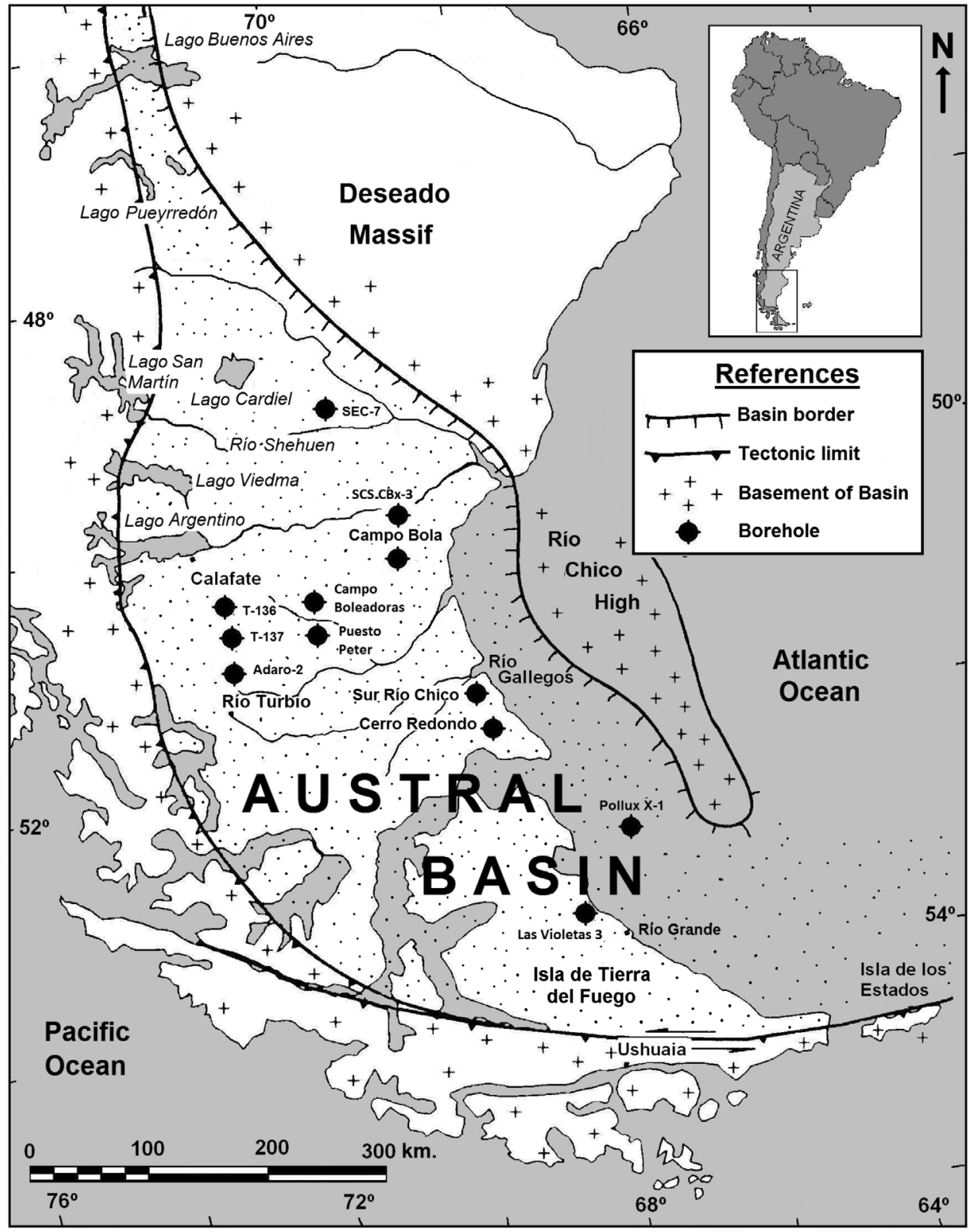

FIG. 1. Austral Basin and location of the studied boreholes (map modified from Nullo et al., 1999)

fine to medium grained sandstones with intercalated claystones and coquinas. The Danian age is based on foraminifer assemblages with Buliminella isabelleana Camacho and Globoconusa daubjergensis (Brönimann) among others (Malumián, 1999), and on nannofossil assemblages with Toweius africanus, Cruciplacolithus primus and Hornibrookina teuriensis (Pérez Panera, 2007, 2009). Other well-known fossils from these sedimentary rocks are a highly bio-diverse palynoflore, in which Nothofagidites sp. is the most conspicuous genus; and macrofossils, where the most important are the mollusks (Romero, 1979, 1986; Griffin and Hünicken, 1994). During the Late Paleocene an erosional interval developed along the edges of the basin and sedimentation only occurred in the center of the basin. The latter is represented in 


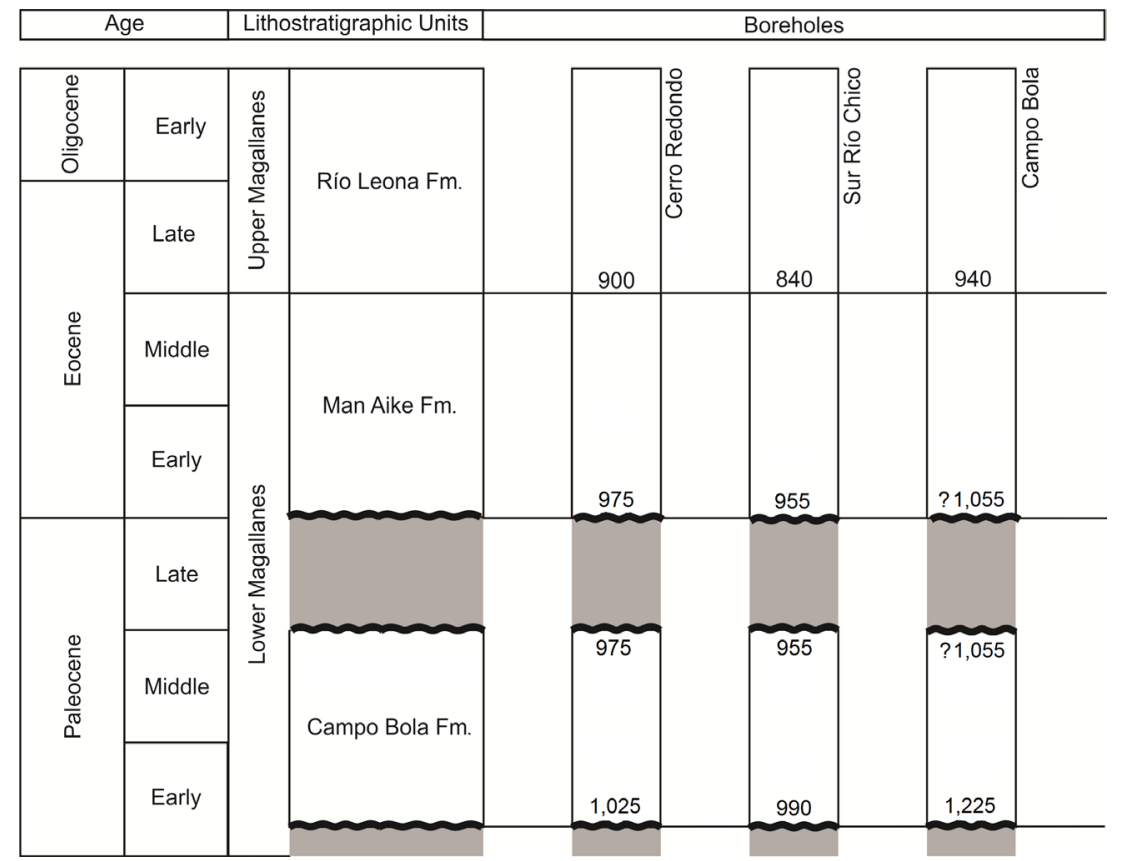

FIG. 2. Formations recognized in the Campo Bola, Sur Río Chico and Cerro Redondo (in Pérez Panera, 2009) boreholes. Number over boreholes columns are sub-bottom depths in meters. Grey areas indicate biostratigraphical hiatus. Not to scale.

Isla Tierra del Fuego and the offshore eastern edge of the basin. These sedimentary rocks are included in the Río Claro and Arroyo Candelaria formations respectively, and they represent marine facies with high phosphorus content (Riggi, 1988; Olivero et al., 1998). To the southwest in Chilean territory, equivalent units are Arcillas de Río Bueno and Agua Fresca formations (Malumián, 1999). During the Early Eocene, a new rise of the sea level is evidenced by marine sedimentation in Isla Tierra del Fuego. Those deposits are represented by Punta Torcida and Agua Fresca formations and in subsurface of Isla Tierra del Fuego by the Margosa inferior Series (Masiuk et al., 1990; Malumián et al., 1994; Malumián and Olivero, 1998; Olivero and Malumián, 1999). The age of these rocks is based on foraminifer assemblages, with Globorotalia wilcoxensis Cushman and Ponton and Planorotalites australiformis (Jenkins), from the Early Eocene (Malumián and Olivero, 1998; Malumián, 1999).

\subsection{Second sedimentary cycle (Early-Middle Eocene)}

After an erosional continental interval characterized by a marine regression and magmatic activity during the Early and Middle Eocene (Malumián, 1999), a new transgression occurred during late Middle Eocene to Late Eocene (Malumián and Náñez, 2011). In the Cordilleran region, thick sequences representing a shallow-interior-marine to estuarine environment were deposited (Malumián, 1999): in Lago Cardiel to Lago Argentino area, these rocks are Eocene in age and assigned to the Man Aike Formation (Concheyro, 1991, 1995; Malumián, 1990, 1999; Casadío et al., 2009), whereas in the Río Turbio area, they belong to Río Turbio Formation. There, Malumián and Caramés (1997) found a high diversity assemblage of benthic foraminifers and ostracods. In Isla Tierra del Fuego the Leticia and Cerro Colorado formations, developed within this second Paleogene cycle, represent the late Middle Eocene and early Late Eocene respectively, according to their microfossil content (Olivero and Malumián, 1999). During this time interval, an antracogenic period that resulted from an extreme warm-climate episode, produced the important carbon-rich beds of the Río Turbio Formation (Malumián, 1999). In the eastern part of the basin, the Middle Eocene subsurface sedimentary rocks are grouped into the upper levels of the Campo Bola Formation (Russo et al., 1980). According to the micropaleontological 
TABLE 1. CORRELATION OF PALEOGENE FORMATIONS WITHIN THE DIFFERENT PARTS OF AUSTRAL BASIN (MODIFIED AFTER MALUMIÁN, 1999 AND RODRÍGUEZ AND MILLER, 2005)

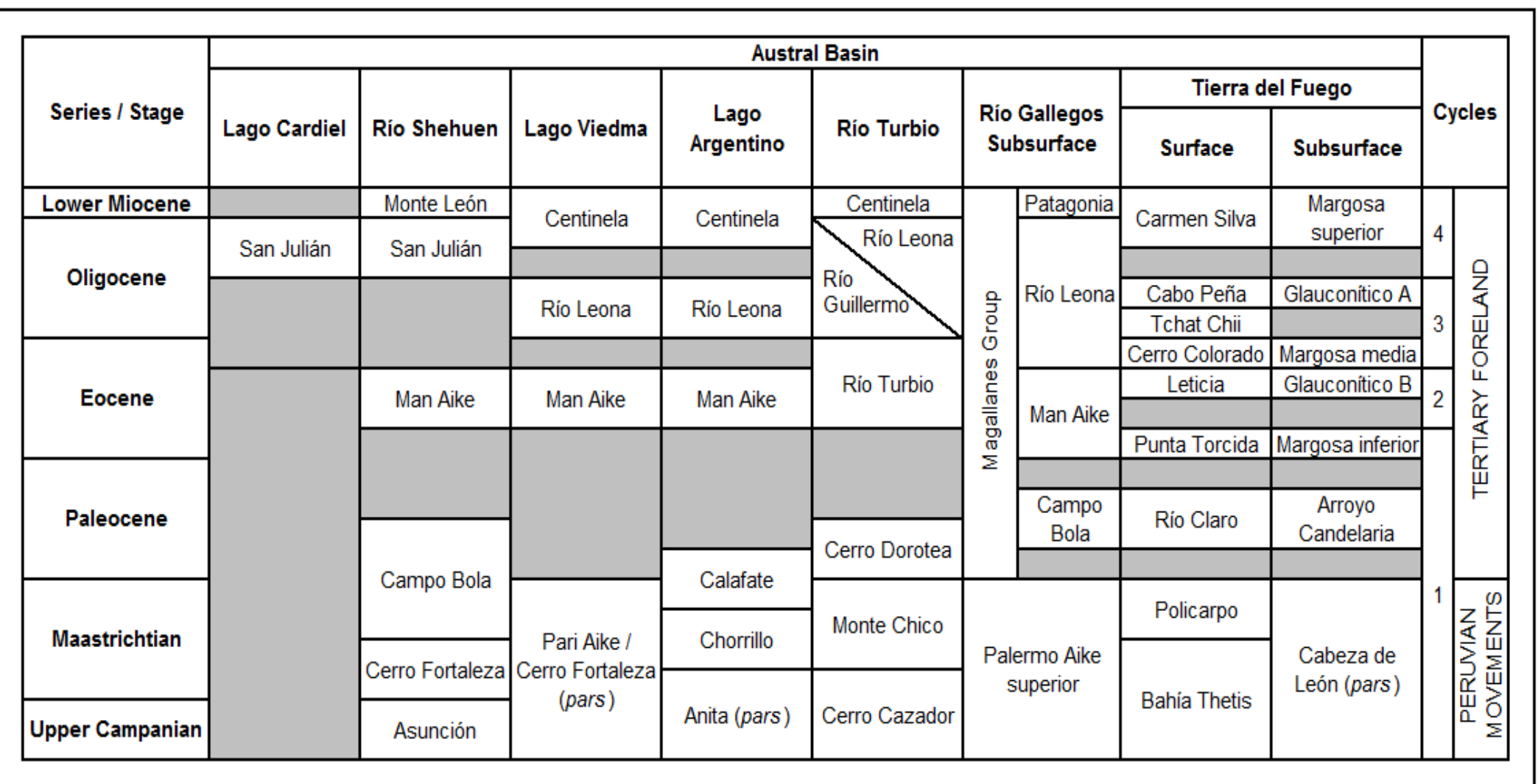


and lithological characteristics of the outcropping Eocene marine sediments grouped in the Man Aike Formation, Malumián (1990) consider it as a senior synonym of Campo Bola Formation.

\subsection{Third sedimentary cycle (Late Eocene-Early Oligocene)}

The third Paleogene cycle ranges from the Late Eocene through the Early Oligocene. Marine sedimentation during this cycle is highly reduced and restricted to the Cabo Peña and San Julián formations that crop out in Isla Tierra del Fuego and in eastern Santa Cruz Province respectively. These rocks yielded a cold-water, Early Oligocene microfauna (Náñez, 1990), although the San Julián Formation is now considered to be Late Oligocene (Malumián and Náñez, 2011). In most parts of the basin this cycle consists of continental conglomerates known as the Río Guillermo Formation in the Río Turbio area and the Tchat-Chii Formation in Isla Tierra del Fuego (Malumián, 1999). These conglomerates are of Late Eocene-Early Oligocene age. Alluvial sedimentary rocks known as Río Leona Formation developed nearly along the entire basin, and it is laterally intercalated with the conglomerates. To the eastern part of the basin this formation is recognized in subsurface, and gave intercalated marine sediments that are more abundant towards the depocenter of the basin (Russo et al.,1980). In the Río Lista area, between Lago Pueyrredón and Lago Buenos Aires, lacustrine carbon-rich rocks represent the end of the antracogenic period initiated during the Middle Eocene (Malumián, 1999). These rocks are of Late Eocene-Early Oligocene age and belong to the Lista Formation.

\section{The Paleogene in the subsurface of the eastern Austral Basin}

As it has been said before, the boreholes here studied are placed in the eastern part of the Austral Basin (Table 1, Río Gallegos subsurface column). The sedimentary rocks of Paleogene-Early Neogene age are widely known as Magallanes Group in the Oil company vocabulary. This is an informal designation that sometimes is divided in a lower member (Magallanes Miembro inferior: Paleocene to late Middle Eocene) and an upper member (Magallanes Miembro superior: Late Eocene to Early Miocene) (Hinterwimmer, 2002). Russo and Flores (1972), and lately Russo et al. (1980) formally defined two formations within these rocks: Campo Bola Formation and Río Leona Formation.

Campo Bola Formation was defined at SCS. CB.X-3 (Campo Bola) borehole as a well developed marine succession with a lower member and an upper member. The lower member is formed by fine to coarse, grey to grizzly, glauconitic-sandstones with poor compaction. In the upper member there is a dominance of grey to grizzly claystones, siltstones and low participation of sandstones (Russo et al., 1980). The whole formation was thought to be of Late Cretaceous age (Russo and Flores, 1972), and later of Middle Eocene to Early Oligocene, based on the similarities of the microfossil associations with the Man Aike Formation (Russo et al., 1980). Malumián (1990) found Campo Bola Formation to be lithologically and micropaleontologically equivalent to Man Aike Formation (Furque, 1973) and he proposed that the latter is the senior synonym of Campo Bola Formation. In subsequent studies (Malumián, 1999; Malumián and Náñez, 2011) retained Campo Bola Formation only for the Late Cretaceous-Paleocene subsurface rocks in the eastern Santa Cruz Province. However, two disconformities observed between the Late Cretaceous-Early Paleocene and the Middle Paleocene-Early to Middle Eocene (Concheyro and Angelozzi, 2002; Pérez Panera, 2009; Ronchi and Angelozzi, 1994) suggests that if the name Campo Bola Formation should be retained it must be restricted to the Paleocene. Underlying and overlying it are the Palermo Aike superior and Man Aike formations, respectively (Table 1, Fig. 2). In this sense, it could be said that the originally defined Campo Bola Formation was later divided, and the upper succession assigned to Man Aike Formation.

The Río Leona Formation was defined to designate the sediments that crop out in the eastern Río Leona area, intercalated between the Man Aike and the Patagonia formations (Russo et al., 1980). It is composed by black to grey and red-yellowish claystones, siltstones, sandstones and conglomerates with carbon-rich claystones and coal layers intercalations (Russo et al., 1980). In the subsurface of eastern Santa Cruz Province this formation can be easily identified due to the coal inclusions and a characteristic of electric profile. It is considered to be continental to estuarine deposits that become more marine towards the depocenter of the basin (Riccardi and Rolleri, 1980). The Río Leona Forma- 
tion is considered to be Middle to Late Oligocene, based more on its stratigraphic position than on its abundant paleoflora (Fig. 2).

\section{Previous studies on Paleogene calcareous nan- nofossils in the Austral Basin}

The first reference to calcareous nannofossils from the Austral Basin are by Charrier and Lahsen $(1968,1969)$ who described an assemblage of low diversity and abundance from the Lower Eocene Agua Fresca Formation in the Chilean sector of the basin. This assemblage is associated with a Late Paleocene-Early Eocene planktonic foraminifer assemblage. Later, Carrizo et al. (1990) described Danian to Middle Eocene microfossils with a sparse assemblage of nannofossils from the Río Turbio area, Cerro Dorotea and Río Turbio formations. Concheyro (1991) described a Middle Eocene calcareous nannofossil assemblage from the subsurface Man Aike Formation at the YCF SEC-7 borehole near Lago Cardiel (Fig.1).

Mostajo (1991) studied the sedimentary successions from Las Violetas-3 borehole on northern Isla Tierra del Fuego (Fig.1). She found Late Paleocene, Early Eocene, Middle Eocene and Oligocene calcareous nannofossil assemblages, and for the deepest levels she also described for the first time a Late Cretaceous assemblage from this basin. On this basis she postulated a stratigraphic discontinuity by the absence of, at least, Lower Paleocene beds.

Ronchi and Angelozzi (1994) studied calcareous nannofossils and foraminifers from Puesto Peter and Campo Boleadoras boreholes (Fig.1), in the central part of the basin, to delimit the Portlandian, Early Valanginian, Valanginian-Hauterivian, AptianAlbian, Coniacian/Santonian, Early Maastrichtian, Late Maastrichtian, Paleocene, late Middle Eocene and Late Oligocene-Early Miocene. They correlated the strata of these boreholes, and postulate shallower marine conditions in the northern Campo Boleadoras borehole during the Late Oligocene-Early Miocene, warm-water conditions during the late Middle Eocene, and delineate several stratigraphical discontinuities. Regarding the Paleogene interval, these discontinuities were identified between the late Maastrichtian and the Paleocene, and between Paleocene and late Middle Eocene.

Concheyro (1995) studied subsurface samples from boreholes YCF SEC-7 (southeast Lago Cardiel); YCF
T-136, YCF T-137, YCF Adaro I (Río Turbio area); and Pollux X-1 (offshore Austral Basin) (Fig. 1). She described and illustrated the Paleogene calcareous nannofossils and grouped them into two major assemblages: 1. Late Paleocene age (NP 9?) with Chiasmolithus bidens as the most important marker, and 2. Middle Eocene age (NP13/14-NP17) with Chiasmolithus grandis, Ch. oamaruensis and Reticulofenestra dictyoda as the most important marker species.

Concheyro and Angelozzi (2002) synthesized previous published studies as well as petroleum-company internal reports on calcareous nannofossils from the Austral Basin. They described and characterized the nannofossil assemblages for the ValanginianHauterivian, Aptian-Albian, Coniacian/Santonian, Campanian, Maastrichtian, Paleocene, Eocene and Oligocene-Miocene.

More recently, Pérez Panera $(2007,2009)$ described: 1. Early Paleocene calcareous nannofossils from southeastern Santa Cruz Province, and 2. Late Campanian, Early Paleocene, Early Eocene and Middle Eocene assemblages from the Cerro Redondo borehole (Figs. 1, 2). In the latter, a series of biostratigraphic nannofossil events were ascertained and are compared herein to the present results.

\section{Material and Methods}

Two hundred twenty-nine Paleogene drill samples from two exploration boreholes were provided by Petrobras-Energía S.A. The boreholes are Sur Río Chico (85 samples) and Campo Bola (144 samples). Their exact names and geographic coordinates are held in confidence by the petroleum company, but figure 1 illustrates their general locations within the basin.

The samples were prepared for study in polarized light using the Standard Gravity Settling Technique of Bramlette and Sullivan (1961). A minimum of 390 fields of view were observed, and the data collected were plotted on a range chart for each borehole along with preservation, abundance and species richness (Tables 2, 3). The preservation criteria is as follows: G: Good, most specimens exhibit little or no secondary alteration; M: Moderate, specimens exhibit the effects of secondary alteration from etching and/or overgrowth (identification of species not impaired); P: Poor, Specimens exhibit intense effects of secondary alteration from etching and/or overgrowth (identification of spe cies impaired but possible in some cases). Total abun- 
dance was calculated by dividing the total specimen count by the total fields of view, and then assigned to a letter category. Letters used in the range charts (Tables 2,3) to denote coccolith species abundances are keyed to the ${ }^{10} \log$ of the number of specimens of a particular taxon likely to be observed in any one field of view of the microscope. This and the corresponding logs are determined as follows: V: Very abundant, more than 10 specimens per field of view; A: Abundant, 1 to 10 specimens per field of view; $\mathbf{C}$ : Common, 1 specimen per 2 to 10 fields of view; F: Few, 1 specimen per 11 to 100 fields of view; R: Rare, 1 specimen per 101 to 1000 fields of view. A petrographic microscope with polarized light at a magnification of $1200 \mathrm{X}$ was used for counting. For the biostratigraphic interpretation the nannofossil events were evaluated according to the schemes of Varol $(1989,1999)$ and correlated with the zonation of Martini (1971). All slides were deposited in the Facultad de Ciencias Exactas y Naturales of the Universidad Nacional de Buenos Aires collection; under BAFC-NP numbers 3558-3642 and 3346-3404 (Tables 2, 3).

\section{Results}

As the study material consists of drilling-cuttings, the results are presented from top to bottom of the drilled section. The nannofossil events recognized in this study are based only on stratigraphical last occurrences (LO) since the recovered assemblages could have contaminants from higher levels.

In general terms, the calcareous nannofossil associations recovered were sparse and with moderate to high taphonomic alteration (Tables 2, 3). The most evident preservation problem is due to overgrowth but etching can also be identified in most of the samples. Three major assemblages were identified at Sur Río Chico, and two at Campo Bola. These assemblages are as follows: Early Paleocene-Middle Paleocene, Early Eocene-Middle Eocene, and Late Eocene-Early Oligocene.

The Late Eocene-Early Oligocene assemblage was recognized in the upper levels of the two boreholes at depths of 230 to $840 \mathrm{~m}$ at Sur Río Chico and 270 to $925 \mathrm{~m}$ at Campo Bola (Tables 2, 3). At these levels, the calcareous nannofossils are common to rare in abundance with low species richness index, but some biostratigraphically important species could be identified. This assemblage is characterized by Coccolithus pelagicus, Chiasmolithus oamaruensis,
Cruciplacolithus staurion, Helicosphaera ethologa, Lanternithus minutus, Reticulofenestra bisecta, $R$. dictyoda, R. minuta, $R$. umbilica and Thoracosphaera spp. Some nannofossil events were recognized within this succession: the LO of Lanternithus minutus at 280$270 \mathrm{~m}$ in Campo Bola indicates an age not younger than Early Oligocene (base of Zone NP23). The LO of Reticulofenestra umbilica at 430-440 and 230-240 m in Campo Bola and Sur Río Chico respectively, marks the top of Zone NP22. In Sur Río Chico at 290-300 $\mathrm{m}$ depth, the LO of Reticulofenestra reticulata was recorded; even when it is not a very frequent species in the assemblage, it is considered to be an important bio-event at the base of Zone NP21 in the North Sea (Varol, 1999). The LO of Cruciplacolithus staurion and Chiasmolithus grandis marks the top of Zone NP17. Whereas $C h$. grandis was not useful in this study due to its low abundance, the $\mathrm{LO}$ of $C$. staurion at $300 \mathrm{~m}$ in Sur Río Chico and $555 \mathrm{~m}$ in Campo Bola, allowed the identification of the Middle Eocene/Upper Eocene boundary (Tables 2, 3).

The Early Eocene-Middle Eocene assemblage was recorded at depths of 840 to $955 \mathrm{~m}$ in Sur Río Chico and 965 to $1055 \mathrm{~m}$ at Campo Bola (Tables 2, 3). At these levels, the calcareous nannofossils are also sparse but more abundant than in the upper levels. The assemblage is characterized by Coccolithus pelagicus, Chiasmolithus solitus, Ch. modestus, Ch. consuetus, Reticulofenestra bisecta bisecta, $R$. bisecta filewiczii, $R$. daviesii, $R$. dictyoda, R.minuta, Thoracosphaera spp; and, in the deepest levels of Sur Río Chico, also by Chiasmolithus bidens and Toweius spp. Some globally recognized nannofossil events were identified within these successions: the LO of Chiasmolithus solitus together with the LO of Ch. modestus allowed the correlation of the top of Zone NP16 between the two boreholes, at 840-850 and 965-970 m depth in Sur Río Chico and Campo Bola respectively (Tables 2, 3). Below that boundary, in Sur Río Chico the LO of Chiasmolithus bidens and Toweius eminens at 950-930 m marks the top of zones NP11 and NP10 respectively, hence it is interpreted that the assemblage is of Early Eocene to Middle Eocene age. At the Campo Bola borehole succession, apart from Zone NP16, Zone NP13 could be interpreted based on the presence of Chiasmolithus eograndis. Thus, the assemblage recovered at Campo Bola is late Early Eocene to Middle Eocene age. Below that level, at 1,050-1,055 $\mathrm{m}$ depth, all samples are barren and the correlation with Sur Río Chico is lost (Tables 2, 3). 
TABLE 2 A. RANGE CHART FOR SUR RÍO CHICO.

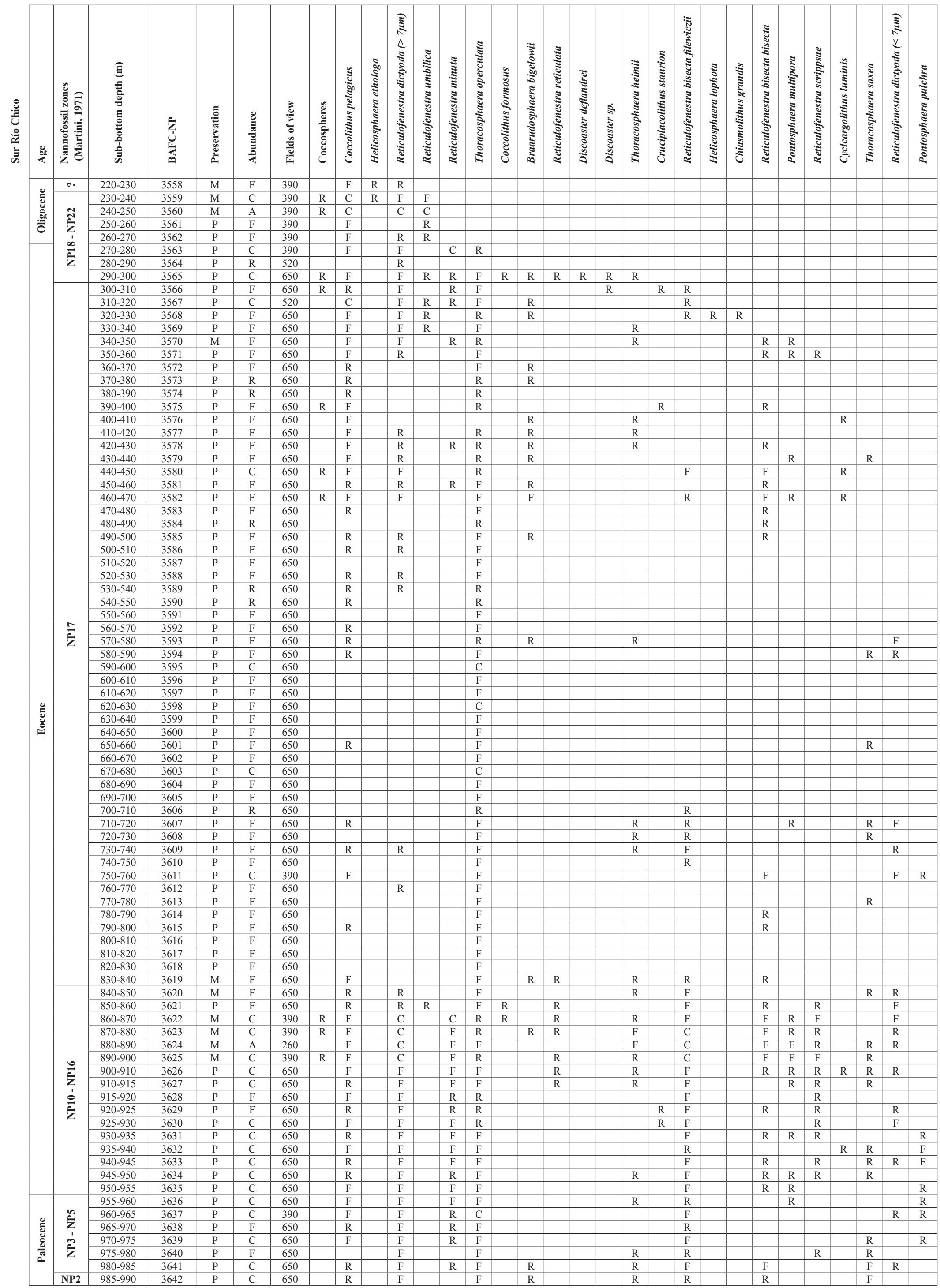


TABLE 2B. RANGE CHART FOR SUR RÍO CHICO.

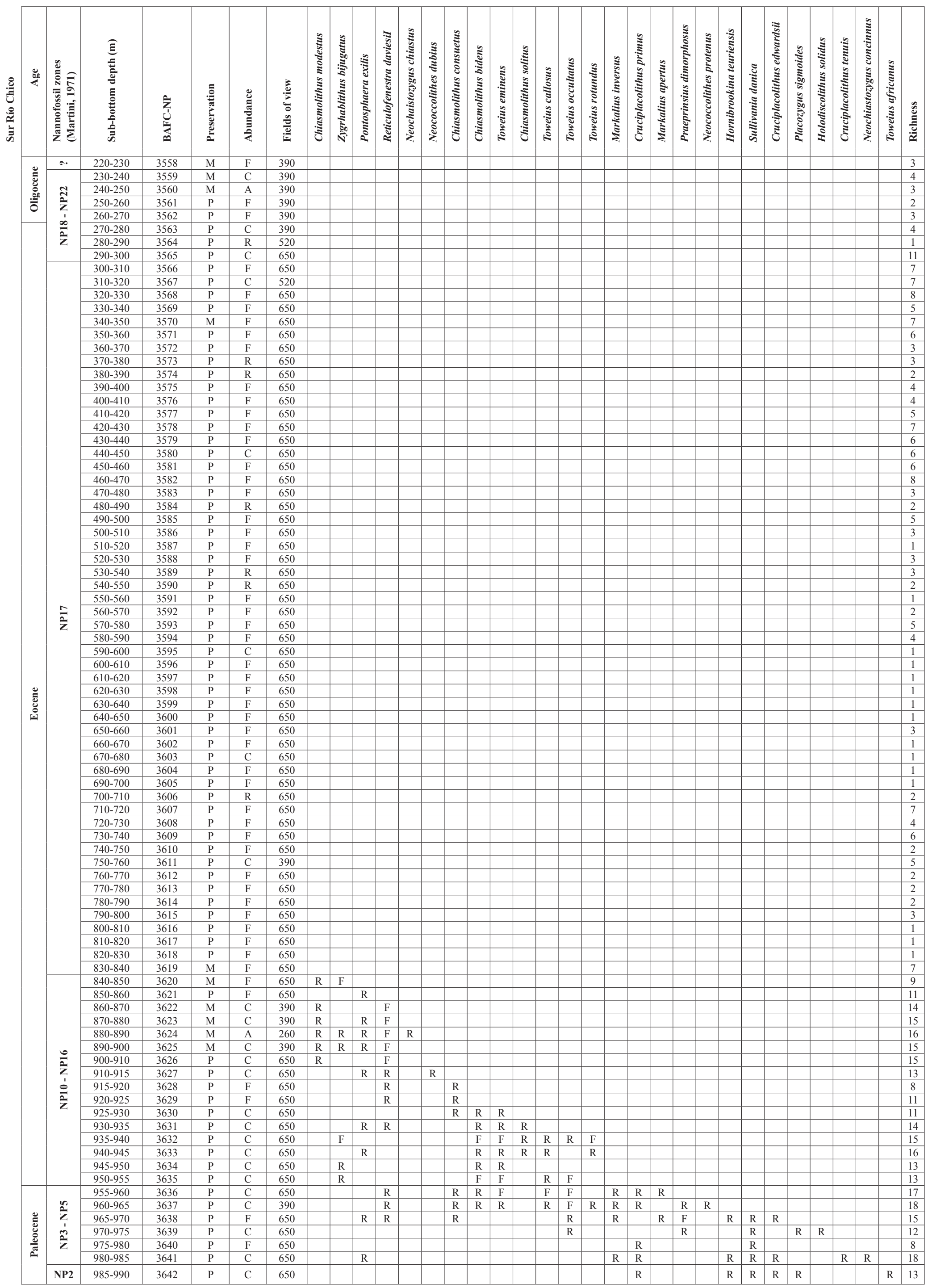

Preservation: G: Good (not recordered); M: Moderate; P: Poor. Abundance; A: Abundant; C: Common; F: Frequent; R: Rare. 
TABLE 3. RANGE CHART FOR CAMPO BOLA.

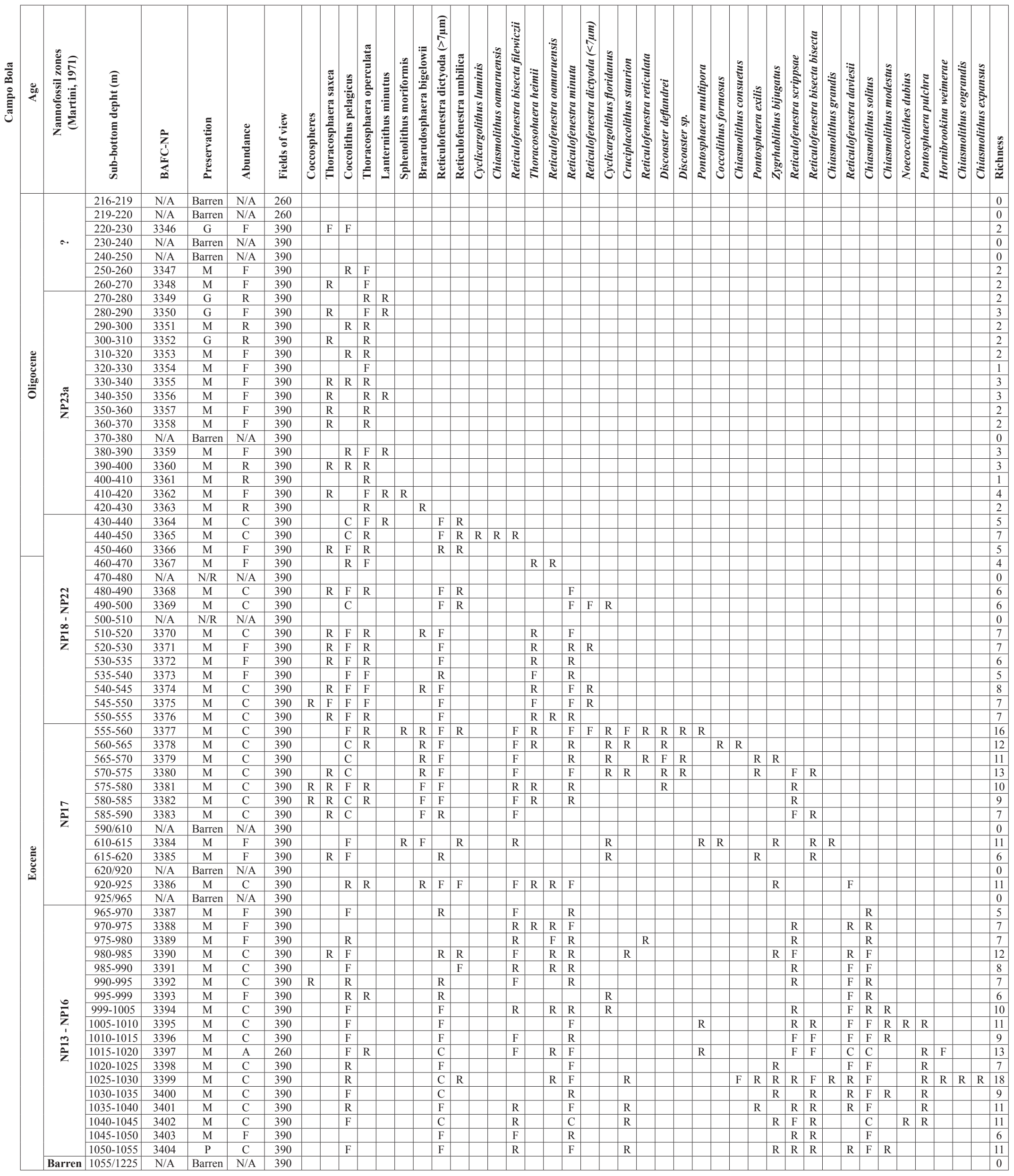

Preservation: G: Good; M: Moderate; P: Poor. Abundance; A: Abundant; C: Common; F: Frequent; R: Rare; N/A: Not Applicable; N/R: Not Recovered 


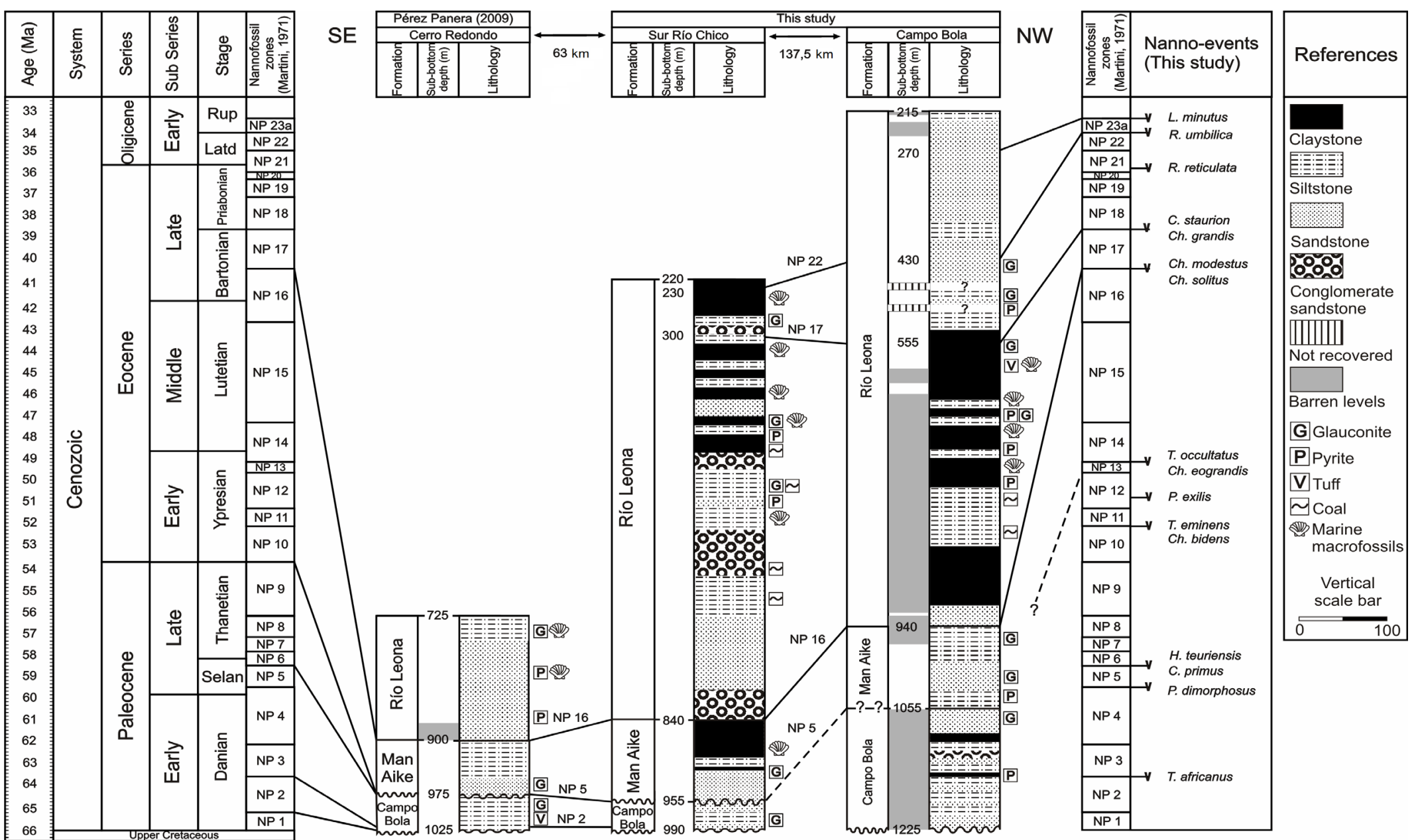

FIG. 3. Stratigraphic correlation of Sur Río Chico, Campo Bola and Cerro Redondo boreholes. Nannofossil zones are from Martini (1971). Timing of recognized nannofossil events in this study are according to Varol (1999). Horizontal dimension not to scale. 
An Early Paleocene-Middle Paleocene assemblage (NP2 to NP5) was recorded at Sur Río Chico from 955 to $990 \mathrm{~m}$ (Tables 2, 3). Beneath that depth a Late Maastrichtian calcareous nannofossil assemblage had been recognized (Pérez Panera, 2012). This assemblage is also of low abundance and poor preservation, however, some important marker species of DanianSelandian age could be identified. It is characterized by Cruciplacolithus edwardsii, C. primus, C. tenuis, Hornibrookina teuriensis, Markalius apertus, M. inversus, Praeprinsius dimorphosus, Sullivania danica and Thoracosphaera spp. The presence of Toweius africanus at the base of the succession marks the top of Zone NP2.

\section{Discussion}

As mentioned previously, the Paleogene calcareous nannofossils assemblages found in the examined boreholes are sparse and in most cases the preservation show moderate to high overgrowth and etching; however, it has been possible to identify some globally important nannofossil events and marker species (Fig. 3). Most biostratigraphically relevant species found in this contribution are ilustrated in figure 4. Both boreholes (Campo Bola and Sur Río Chico) are correlated with each other and also with Cerro Redondo borehole, previously studied by Pérez Panera (2009), placed $63 \mathrm{~km}$ south from Sur Río Chico. This correlation is shown in figure 3. The base line for the correlations is the Cretaceous/ Paleogene boundary. In Campo Bola borehole, the deepest samples are barren so it is uncertain where that boundary is. However, at 1,225-1,230 m depth, an agglutinated foraminifer assemblage of the Late Cretaceous informal zone of 'arenaceous foraminifers' of Malumián and Masiuk (1976) had been recovered (personal communication, D. Ronchi, 2010). Therefore sample $1220-1225$ is used here as the base of the succession.

Following Malumián (1999, 2002), the Paleogene depocenter of the basin is placed to the southeast, over the Argentinean Continental Platform and Isla Tierra del Fuego. That could explain why the Paleocene in Campo Bola, $137.5 \mathrm{~km}$ northwest of Sur Río Chico, could not be identified on the basis of calcareous nannofossils. It is quite probable that the Late Maastrichtian-Early Eocene transgression did not deposit sufficiently deep marine sediments in that part of the basin. On the other hand, at Sur Río Chico and also Cerro Redondo (Pérez Panera,
2009), an Early Paleocene-Middle Paleocene nannofossil assemblage was recorded. The sediments yielding these assemblages lie over an erosional or non-depositional surface based on the absence of upper Maastrichtian (Cerro Redondo in Pérez Panera, 2009) and lower Danian (Cerro Redondo and Sur Río Chico) sedimentary rocks. Both in Cerro Redondo and Sur Río Chico boreholes, Toweius africanus, a high-latitude nannofossil restricted to Zone NP2 (Perch-Nielsen, 1985) was recorded just in the lowermost levels (Table 2). Above them, Praeprinsius dimorphosus, and in higher levels Hornibrookina teuriensis, have their LOs. Sullivania danica, another important marker species from zones NP3 to NP6 (Varol, 1989, 1999) is a recurrent species in these assemblages. The lithology where these assemblages were recorded is argillaceous silty-sandstones and glauconitic-sandstones that may correspond to the lower member of Campo Bola Formation (sensu Russo et al., 1980). Overlying them, the sediments yield the Early Eocene-Middle Eocene calcareous nannofossil assemblage, thus a discontinuity is interpreted on the basis of a Late Paleocene biostratigraphic hiatus (Pérez Panera, 2009; this study). According to this, Campo Bola Formation is restricted herein to the succession yielding an Early to Middle Paleocene calcareous nannofossil assemblage, that are limited by discontinuities involving the lowermost Danian in the base and the Late Paleocene in the top (Fig. 2). The correlation of Cerro Redondo and Sur Río Chico boreholes with Campo Bola borehole, is difficult because the lower succession at Campo Bola borehole is barren of calcareous nannofossils. However, on the basis of the lithology and the stratigraphic position, Campo Bola Formation was identified but with some difficulties on the determinaton of its upper boundary. In figures 2 and 3 this boundary is located at 1,055 m, under the silty-sandstones and sandstones yielding the late Early Eocene- Middle Eocene calcareous nannofossil assemblages with a dotted line.

At the Sur Río Chico borehole, the following LOs were recorded in the beds overlying the Campo Bola Formation: Toweius occultatus (935-940 m), Chiasmolithus solitus (930-935 m), Chiasmolithus bidens and Toweius eminens (925-930 m), Pontosphaera exilis (850-860 m), and Chiasmolithus modestus (840$850 \mathrm{~m}$ ) (Table 2). All these nannofossil events have global biostratigraphical significance (Varol, 1989, 1999). However, here they are recorded somehow chaotically. For instance, the LO of Ch. solitus should 

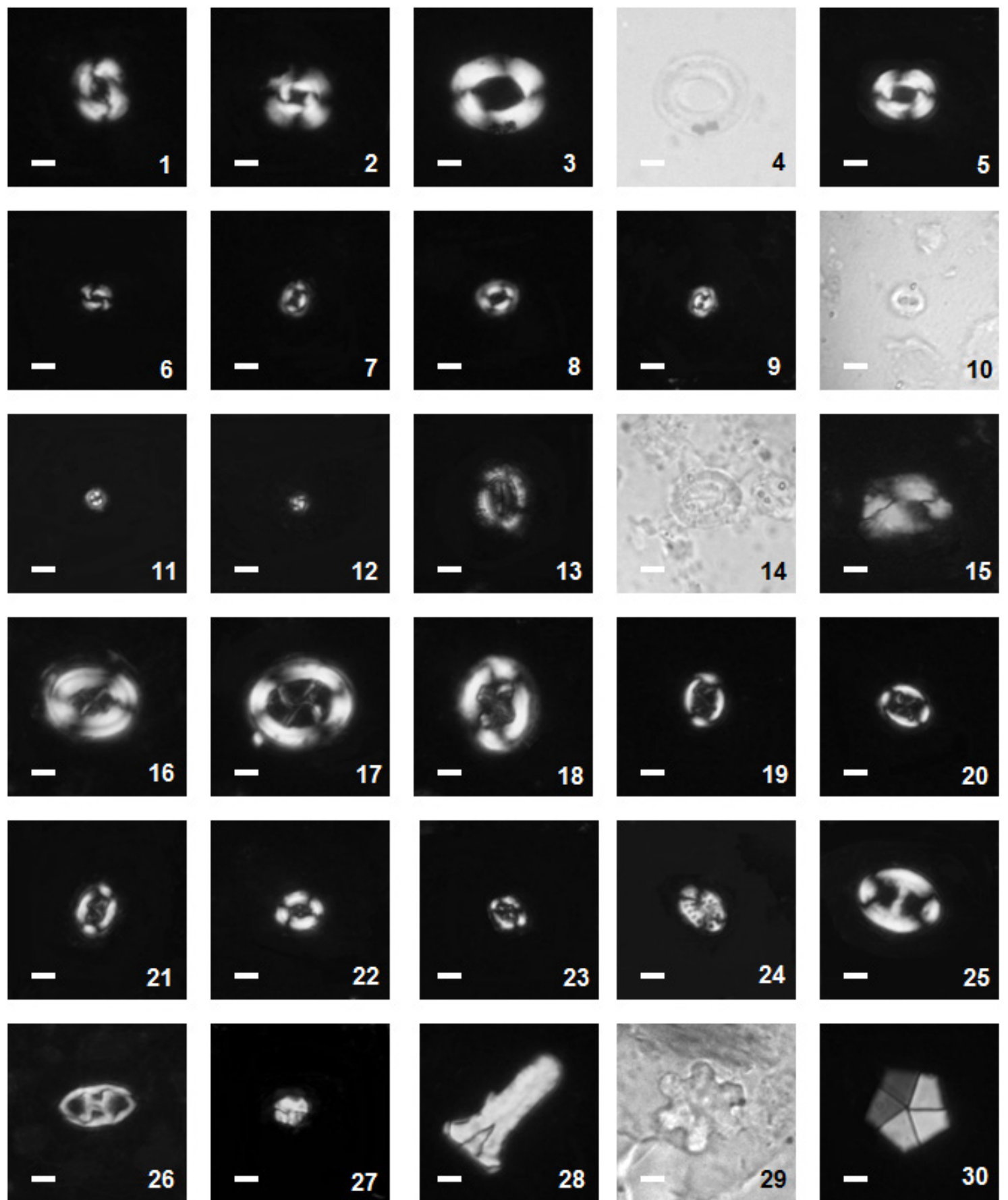

FIG. 4. Biostratigraphic or paleoceanographic relevant paleogene calcareous nannofossils from Austral Basin. Scale bar: $3 \mu \mathrm{m} ; 1$. Reticulofenestra daviesii (Haq, 1968, 1971), cross-polarized light, BAFC-NP 3632; 2. Reticulofenestra reticulata (Gartner and Smith, 1967) Roth and Thierstein, 1972, cross-polarized light, BAFC-NP 3632; 3-4. Reticulofenestra umbilica (Levin, 1965) Martini and Ritzkowski, 1968, cross-polarized light (3), transmitted light (4), BAFC-NP 3399; 5. Reticulofenestra dictyoda (Deflandre in Deflandre and Fert, 1954) Stradner in Stradner and Edwards, 1968 (>7 $\mu \mathrm{m}$ ), cross-polarized light, BAFC-NP 3378 ; 6. Reticulofenestra dictyoda (Deflandre in Deflandre and Fert, 1954) Stradner in Stradner and Edwards, $1968(<7 \mu \mathrm{m})$, cross-polarized light, BAFC-NP 3641; 7. Toweius eminens (Bramlette and Sullivan, 1961) Perch-Nielsen, 1971, crossed-polarized light, BAFC-NP 3632; 8. Toweius callosus Perch-Nielsen, 1971, cross-polarized light, BAFC-NP 3632; 9-10. Toweius occultatus (Locker, 1967) Perch-Nielsen, 1971, crossed-polarized light (9), transmitted light (10), BAFC-NP 3635; 11. Toweius a fricanus (Perch.Nielsen, 1980) Perch-Nielsen, 1984, crossed-polarized light, BAFC-NP 3642; 12. Praeprinsius dimorphosus (Perch-Nielsen, 1969) Varo and Jakubowski, 1989, cross-polarized light, BAFC-NP 3638; 13-14. Hornibrookina teuriensis Edwards, 1973, cross-polarized light (13), transmitted light (14), BAFC-NP 3641; 15. Helicosphaera ethologa Bown, 2005, cross-polarized light, BAFC-NP 3559; 16. Chiasmolithus modestus Perch-Nielsen, 1971, cross-polarized light, BAFC-NP3626; 17. Chiasmolithus eograndis Perch-Nielsen, 1971, cross-polarized light, BAFC-NP 3399; 18. Chiasmolithus bidens (Bramlette and Sullivan, 1961) Hay and Mohler, 1967, cross-polarized light, BAFC-NP 3632; 19-20. Chiasmolithus solitus (Bramlette and Sullivan, 1961) Locker, 1968, cross-polarized light, BAFC-NP 3397; 21. Sullivania danica (Brotzen, 1959) Varol, 1992, cross-polarized light, BAFC-NP 3638; 22. Cruciplacolithus staurion (Bramlette and Sullivan, 1961) Gartner, 1971, cross-polarized light, BAFC-NP 3629; 23. Cruciplacolithus primus Perch-Nielsen, 1977, cross-polarized light, BAFC-NP 3641; 24. Pontosphaera multipora (Kamptner, 1948 ex Deflandre, 1954) Roth, 1970, crossed-polarized light, BAFC-NP 3377; 25. Pontosphaera exilis (Bramlette and Sullivan, 1961) Romein, 1979, cross-polarized light, BAFC-NP 3399; 26. Neococcolithes dubius (Deflandre in Deflandre and Fert, 1954) Black, 1967, cross-polarized light, BAFC-NP 3399; 27. Lanternithus minutus Stradner, 1962, cross-polarized light, BAFC-NP 3362; 28. Zigrhablithus bijugatus (Deflandre 1959, in Deflandre and Fert, 1954) Deflandre, cross-polarized light, BAFC-NP 3399; 29. Discoaster deflandrei Bramlette and Riedel, 1954, cross-polarized light, BAFC-NP 3565; 30. Braarudosphaera bigelowii (Gran and Braarud, 1935) Deflandre, 1947, cross-polarized light, BAFC-NP 3593. 
have been recorded at the same level as the LO of Ch. modestus, and the LO of T. occultatus at higher levels from the LOs of Ch. bidens, $P$. exilis and $T$. eminens. This strange distribution does not means that those nannofossil events are not biostratigraphically useful in the Austral Basin, but may indicate that the sampling and/or the preservation is not sufficient for a more detailed and precise biostratigraphic zonation in this particular case. For this reason, the segment between 950-955 to 840-850 m depth at Sur Río Chico is considered to be Early Eocene to Middle Eocene in age (zones NP10 to NP16). In Campo Bola a late Early Eocene-Middle Eocene assemblage overlying the barren levels was recorded. The LO of Ch. modestus (999-1,005 m) and LO of Ch. solitus (965-970 m) are the most important nannofossil events found (Table 3). Again, it is apparent that the sampling and/or preservation are not sufficient for a more detailed biostratigraphic study. Overlying these strata is a 340-m-thick succession barren of calcareous nannofossils, so the top of the late Early-Middle Eocene calcareous nannofossil assemblage bearing succession (965-970 m) is correlated with the top of the Early Eocene-Middle Eocene succession at Sur Río Chico (Fig. 3). This correlation is based on the LOs of Ch. solitus and Ch. modestus, both indicative of the top of Zone NP16. The results obtained at Sur Río Chico and Campo Bola implies that a reinterpretation of the Cerro Redondo data in Pérez Panera (2009) is needed. In the latter, each sample covered a 25-m interval and the assemblages are very similar to those at Sur Río Chico. For the succession between 950-975 to 900-925 m at Cerro Redondo, Pérez Panera (2009) interpreted a late Early EoceneMiddle Eocene assemblage with a biostratigraphic hiatus in between (zones NP13 and NP15 to NP16). The comparison of the assemblages recorded at Cerro Redondo and Sur Río Chico shows that the apparent Zone NP14 hiatus observed at Cerro Redondo is most likely due to the $25-\mathrm{m}$ sampling intervals and preservation problems. Also, the age at the base of the succession in Cerro Redondo is extended to the Early Eocene (NP10), on the basis of the marker Toweius eminens, now found to be present there. The sediments bearing the Early Eocene-Middle Eocene nannofossil asemblages are glauconitic-sandstones that change to silty-sandstones with intercalated claystone-levels to the top of the succession. These lithological characteristics and the stratigraphical position above the Late Paleocene hiatus, suggests that this succession corresponds to the Man Aike Formation (Fig. 2).

Overlying the Early Eocene-Middle Eocene succession at Sur Río Chico and Campo Bola is a Late Eocene to Early Oligocene nannofossil assemblage (from 830-840 to 220-230 m and 920-925 to 216$219 \mathrm{~m}$, respectively). In the case of Campo Bola, this assemblage actually overlies the $340 \mathrm{~m}$-thick barren succession. Within these rocks, the LO of Cruciplacolithus staurion at 300-310 m in Sur Río Chico and at 555-560 $\mathrm{m}$ in Campo Bola indicate the top of Zone NP17 (Varol, 1999). At higher levels, the LO Reticulofenestra umbilica (230-240 and 430-440 m at Sur Río Chico and Campo Bola respectively) allows correlation and indicates an age older than Latfordian (Early Oligocene). In Campo Bola, at 270-280 m the LO of Lanternithus minutus confirms an Early Oligocene age for the assemblage (Tables 2, 3). The assemblage is sparse in numbers, but again, some globally important nanno-events can be observed. Even, in the samples assigned to the early Late Eocene (NP17), Discoaster deflandrei and other poorly-preserved unidentified discoasters are present. Discoasters are well known warm-water indicators, common in the low to middle paleolatitudes. The presence of these forms only in those samples is consistent with the proposal of the end of the warm period at 39 Ma (Malumián, 1999; Malumián and Jannou, 2010; Malumián and Náñez, 2011; Ronchi and Angelozzi, 1994). The lithology of this succession in the three boreholes starts with conglomerate-sandstones or sandstones that in the upper levels yield some intercalated silty-sandstones and grey to black claystones. In the whole succession there are sporadic leveles with coal intercalations, glauconite and pyrite. Therefore, this succession is included in the eastern marginal-sea facies of Río Leona Formation (Fig. 2). The correlation between Cerro Redondo, Sur Río Chico and Campo Bola (Fig. 3) shows the penetration of the Paleogene marine transgressions and the southeast-northwest orientation of the depocenter. In the northern Campo Bola borehole the fine to medium-grained sediments with pyrite, coal, and glauconite inclusions, and barren of calcareous nannofossils in the base of the succession, are interpreted as restricted, shallowmarine environments with some continental-sediment progradation. It is the development of normal marine environments during the Middle Eocene-Early Oligocene that provide a widespread marine transgression 
throughout the basin (Malumián, 1993; Malumián and Náñez, 2002, 2011).

\section{Conclusions}

Three major Paleogene calcareous nannofossil assemblages have been recorded in the subsurface of the eastern Austral Basin. These are of Early PaleoceneMiddle Paleocene (NP2-NP5), Early Eocene-Middle Eocene (NP 10-NP16) and Late Eocene-Early Oligocene (NP17-NP23) age. These assemblages match with the subsurface eastern formations Campo Bola, Man Aike and Río Leona respectively. These formations also represent the oldest three sedimentary cycles within the Paleogene of the Austral Basin. On the basis of the nannofossil associations two discontinuities due to biostratigraphical hiatuses were recognized. The oldest is placed in the base of the Campo Bola Formation and occurs between the lowermost Danian and the subjacent Upper Cretaceous succession. The youngest, is placed between Campo Bola and Man Aike formations and involves at least the Late Paleocene.

The sedimentary succession in the southern Cerro Redondo and Sur Río Chico boreholes exhibit an almost continuous record of calcareous nannofossils of Early to Middle Paleocene and Eocene to Early Oligocene age; whereas the northern Campo Bola borehole succession yielded only late Early Eocene to Early Oligocene assemblages with thick barren levels. These barren sections are thought to be restricted to shallow-marine to continental sediments due to the marginal position of this site in the basin.

\section{Acknowledgements}

This study was possible thanks to Petrobras-Energía S.A. Argentina, that through M. Cagnolatti and F. Pángaro kindly provided the samples; and to G. Angelozzi and D. Ronchi (GEMA S.R.L., Argentina) who provided equipment support. The author also thanks Dr. S.W. Wise (Florida State University, USA) for a critical reading of the manuscript and editorial comments. This contribution was improved due to the comments of Dr. M. Suárez (Andean Geology editor), an anonymous reviewer, Dr. A. Rubilar (Servicio Nacional de Geología y Minería, Chile) and Dr. N. Malumián (CONICET-SEGEMAR, Argentina). The photographs were taken at the laboratories of Department of Earth, Ocean \& Atmospheric Science, Carraway Bldg., Florida State University, Tallahassee, Florida, USA. Dr. A. P. Carignano (CONICET, Argentina) helped with figure 3.
Financial support was provided by the Consejo Nacional de Investigaciones Científicas y Técnicas (CONICET, Argentina) through grant PIP 00819.

\section{References}

Biddle, K.T.; Uliana, M.A.; Mitchum Jr. R.M.; Fitzgerald, M.G.; Wright, R.C. 1986. The Stratigraphic and structural evolution of the central and eastern Magallanes Basin, southern South America. In Foreland Basins (Allen, P.A.; Homewoods, P.; editors). International Association of Sedimentologists, Special Publication, Blackwell 8: 41-61.

Bramlette, M.N.; Sullivan, F.R. 1961. Coccolithophorids and related nannoplankton of the early Tertiary in California. Micropaleontology 2: 129-188.

Carrizo, R.; Malumián, N.; Náñez, C.; Caramés, A.; Concheyro, A. 1990. Micropaleontología y correlación del Terciario del área carbonífera de Río Turbio, provincia de Santa Cruz, Argentina. In Simposio sobre el Terciario de Chile, No. 2, Procesos y Productos de Depositación en el ámbito Andino, Actas 1:29-50.

Casadío, S.; Griffin, M.; Marenssi, S.; Net, L.; Parras, A.; Rodríguez Raising, M.; Santillana, S. 2009. Paleontology and sedimentology of Middle Eocene rocks in Lago Argentino area, Santa Cruz Province, Argentina. Ameghiniana 46: 27-47.

Charrier, R.; Lahsen, A.A. 1968. Contribution a l'etude de la limite Crétacé - Tertiaire de la Province de Magellan, extreme Sud du Chili. Revue de Micropaléontologie 11: 111-120.

Charrier, R.; Lahsen, A.A. 1969. Stratigraphy of the Late Cretaceous-Early Eocene Seno Skyring-Strait of Magellan Area, Magallanes Province, Chili. Bulletin of the American Association of Petroleum Geologists 53: 568-590.

Codignotto, J.C.; Malumián, N. 1981. Geología al norte de la Isla Grande de Tierra del Fuego. Revista de la Asociación Geológica Argentina 36: 44-88.

Concheyro, A. 1991. Nanofósiles calcáreos de la Formación Man Aike (Eoceno, Sudeste del Lago Cardiel) Santa Cruz, Argentina. Ameghiniana 28: 385-399.

Concheyro, A. 1995. Nanofósiles calcáreos del Cretácico Superior y Paleógeno de Patagonia, Argentina. Tesis Doctoral (Inédita), Facultad de Ciencias Exactas y Naturales, Universidad Nacional de Buenos Aires 1: 1-133; 2: 1-176.

Concheyro, A.; Angelozzi, G.N. 2002. Nanofósiles calcáreos de la provincia de Santa Cruz, Argentina. In Geología y recursos naturales de la provincia de Santa Cruz (Haller, 
M.J.; editor). Congreso Geológico Argentino, No. 15, Relatorio 9: 495-517. El Calafate.

Furque, G. 1973. Descripción geológica de la hoja 58b Lago Argentino. Boletín del Servicio Nacional Minero y Geológico 104: 1-49.

Griffin, M.; Hünicken, M.A. 1994. Late Cretaceous-Early Tertiary Gastropods from the Southwestern Patagonia, Argentine. Journal of Paleontology 68: 257-274.

Guerstein, G.R.; Junciel, G.L.; Guler, M.V.; Daners, G. 2005. Diconodinium lurense sp. nov., a late Maastrichtian to Danian dinoflagellate cyst from southwest Atlantic basins. Ameghiniana 42: 329-338.

Hinterwimmer, G. 2002. Los reservorios de la Serie Tobífera. In Rocas Reservorio de las cuencas productivas de la Argentina (Schiuma, M; Hinterwimmer, G.; Vergani, G.; editors). Congreso de Exploración y Desarrollo de Hidrocarburos, No. 5, Actas: 27-47.

Malumián, N. 1990. Foraminíferos de la Formación Man Aike (Eoceno, sureste Lago Cardiel) provincia de Santa Cruz. Revista de la Asociación Geológica Argentina 45: 365-385.

Malumián, N. 1999. La sedimentación y el volcanismo terciarios en la Patagonia extraandina. In Geología Argentina (Caminos, R; editor). Instituto de Geología y Recursos Minerales, Anales 29: 557-612.

Malumián, N. 2002. El Terciario Marino. Sus relaciones con el eustatismo. In Geología y Recursos Naturales de Santa Cruz (Haller, M.J.; editor). Congreso Geológico Argentino, No. 15, Relatorio I (15): 237-244. El Calafate.

Malumián, N.; Caramés, A. 1995. El Daniano marino de Patagonia (Argentina): Paleobiogeografía de los foraminíferos bentónicos. In Paleógeno de América del Sur (Náñez, C; editor). Asociación Paleontológica Argentina, Publicación Especial 3: 83-105.

Malumián, N.; Náñez, C. 1996. Microfósiles y nanoplancton calcáreo de la Plataforma Continental. In Geología y Recursos Naturales de la Plataforma Continental Argentina (Ramos, V.A.; Turic, M.A.; editors). In Congreso Geológico Argentino, No. 13 y Congreso de Exploración de Hidrocarburos, No. 3, Relatorio: 73-93.

Malumián, N.; Caramés, A. 1997. Upper CampanianPaleogene from Río Turbio coal measures area: micropaleontology and the Paleocene/Eocene boundary. Journal of South American Earth Sciences 10: 189-201.

Malumián, N.; Náñez, C. 1998. El género Transversigerina y la edad de la transgresión patagoniana. In Congreso Latinoamericano de Geología, No. 10 y Congreso Nacional de Geología Económica, No. 6, Actas 1: 285-290.
Malumián N.; Olivero, E.B. 1998. La Formación Río Bueno, relaciones estratigráficas y edad. Eoceno inferior, Isla Grande de Tierra del Fuego, Argentina. In Congreso Latinoamericano de Geología, No. 10 y Congreso Nacional de Geología Económica, No. 6, Actas 1: 120-124.

Malumián, N.; Náñez, C. 2002. Los foraminíferos. Su significado geológico y ambiental. In Geología y Recursos Naturales de Santa Cruz (Haller, M.J.; editor). Congreso Geológico Argentino, No. 15, Relatorio II (8): 481-493. El Calafate.

Malumián, N.; Jannou, G. 2010. Los Andes Fueguinos: el registro micropaleontológico de los mayores acontecimientos paleooceanográficos australes del Campaniano al Mioceno. Andean Geology 37 (2): 345-374.

Malumián, N.; Náñez, C. 2011. The Late CretaceousCenozoic transgressions in Patagonia and the Fuegian Andes: foraminífera, palaeoecology, and palaeogeography. Biological Journal of the Linnean Society 103: 269-288.

Malumián, N.; Masiuk, V.; Riggi, J.C. 1971. Micropaleontología y sedimentología de la perforación SC1, provincia de Santa Cruz, República Argentina, su importancia y correlaciones. Revista de la Asociación Geológica Argentina 24: 175-208.

Malumián, N.; Olivero, E.B.; Concheyro, A. 1994. Eocene microfossils from the Leticia Formation, Tierra del Fuego Island, Argentina. Reunión anual de Comunicaciones de la Asociación Paleontológica Argentina, Resúmenes. Ameghiniana 31: 398.

Marenssi, S.A.; Guler, M.V.; Casadío, S.; Guerstein, G.R.; Papú, O. 2004. Sedimentology and biostratigraphy of Maastrichtian deposits from Austral Basin, Argentina. Cretaceous Research 25: 907-918.

Martini, E. 1971. Standard Tertiary and Quaternary calcareous nannoplankton zonation. In Planktonic Conference, No. 2 (Farinacci, A.; editor), Proceedings 2: 739-785. Roma.

Masiuk, V.; Riggi, J.C.; Bianchi, J.L. 1990. Análisis geológico del Terciario del subsuelo de Tierra del Fuego. Boletín de Informaciones Petroleras 21: 70-89; 22: 8-26.

Mostajo, E.L. 1991. Nanofósiles calcáreos cenozoicos del Pozo 'Las Violetas 3'. Isla Grande de Tierra del Fuego. Argentina. Ameghiniana 28: 311-315.

Náñez, C. 1990. Foraminíferos y bioestratigrafía del Terciario medio del subsuelo de Santa Cruz oriental, Argentina. Revista de la Asociación Geológica Argentina 43: 493-517.

Nullo, F.E.; Panza, J.L.; Blasco, G. 1999. Jurásico y Cretácico de la Cuenca Austral. In Geología Argentina 
(Caminos, R.; editor). Instituto de Geología y Recursos Minerales, Anales 29: 528-535.

Olivero, E.B.; Malumián, N. 1999. Eocene stratigraphy of the Southeastern Tierra del Fuego Island, Argentina. Bulletin of the American Association of Petroleum Geologists 83: 295-313.

Olivero, E.B.; Malumián, N. 2008. Mesozoic-Cenozoic stratigraphy of the Fuegian Andes, Argentina. Geologica Acta 6: 5-18.

Olivero, E.B.; Castro, L.L.; Scasso, R.A.; Fazio, A.M.; Miretzky, P. 1998. Fosfatos marinos del Paleógeno de la Isla Grande de Tierra del Fuego. Revista de la Asociación Geológica Argentina 53: 239-246.

Papú, O. 1997. Nueva especie de Grapnelispora del Campaniense-Maastrichtiense, provincia de Mendoza, Argentina. Inferencias filogenéticas, paleobiogeográficas y paleoambientales. Revista Española de Paleontología 12: 197-205.

Perch-Nielsen, K. 1985. Cenozoic calcareous nannofossils. In Plankton Stratigraphy (Bolli, H.M.; Saunders, J.B.; Perch-Nielsen, K.; editors). Cambridge University Press: 427-554.

Pérez Panera, J.P. 2007. Avances en la micropaleontología del subsuelo de la Cuenca Austral, Argentina: nanofósiles calcáreos. Reunión Anual de Comunicaciones de la Asociación Paleontológica Argentina, Corrientes. Ameghiniana, Resúmenes 44: 98 p.

Pérez Panera, J.P. 2009. Nanofósiles calcáreos paleógenos del sudeste de la provincia de Santa Cruz, Patagonia, Argentina. Ameghiniana 46: 273-284.

Pérez Panera, J.P. 2012. Nanofósiles calcáreos y bioestratigrafía del Cretácico del Sudeste de la Cuenca Austral, Patagonia, Argentina. Ameghiniana 49: 137-163.

Peroni, G.; Cagnolatti, M.; Pedrazzini, M. 2002. Cuenca Austral: Marco geológico y reserva histórica de la actividad petrolera. In Rocas Reservorio de las cuencas productivas de la Argentina (Schiuma, M.; Hinterwimmer, G.; Vergani, G.; editors). Congreso de Exploración y Desarrollo de Hidrocarburos, No. 5: 11-26. Mar del Plata.

Ramos, V.A. 2002. Evolución tectónica. In Geología y recursos naturales de la provincia de Santa Cruz (Haller, M.J.; editor). Congreso Geológico Argentino, No. 15, Relatorio: 365-390. El Calafate.
Riccardi, A.C.; Rolleri, E.O. 1980. Cordillera Patagónica Austral. In Simposio Geología Regional Argentina, No. 2. Academia Nacional de Ciencias de Córdoba 2: 1173-1306.

Riggi, J.C. 1988. Litoestratigrafía terciaria del subsuelo fueguino. Revista de la Asociación Geológica Argentina 43: 106-120.

Robbiano, J.A.; Arbe, H.A.; Gangui, A. 1996. Cuenca Austral Marina. In Geología y Recursos Naturales de la Plataforma Continental Argentina (Ramos, V.A.; Turic, M.A.; editors). Congreso Geológico Argentino, No. 13 y Congreso de Exploración de Hidrocarburos, No. 3, Relatorio 17: 323-341. Buenos Aires.

Rodríguez, J.F.; Miller, M. 2005. Cuenca Austral. In Frontera Exploratoria de la Argentina (Chebli, G.A.; Cortiñas, J.S.; Spalletti, L.A.; Legarreta, L.; Vallejo, E. L.; editors). Congreso de exploración y Desarrollo de Hidrocarburos, No. 6, Actas 15: 307-323. Mar del Plata.

Romero, E.J. 1979. Paleoecología y fitogeografía de las tafofloras del Cenofítico de Argentina y áreas vecinas. Ameghiniana 15: 209-227.

Romero, E.J. 1986. Paleogene phytogeography and climatology of South America. Annals of the Missouri Botanical Garden 73: 449-461.

Ronchi, D.I.; Angelozzi, G.N. 1994. Bioestratigrafía del Cretácico-Terciario en dos pozos ubicados al oeste de la Cuenca Austral. Boletín de Informaciones Petroleras 39: 65-76.

Russo, A.; Flores, M.A. 1972. Patagonia Austral extra andina. In Geología Regional Argentina (Leanza, A. F.; editor). Academia Nacional de Ciencias: 707-725. (Córdoba).

Russo, A.; Flores. M.A.; Di Benedetto, H. 1980. Patagonia austral extraandina. In Simposio Geología Regional Argentina, No. 2. Academia Nacional de Ciencias 2: 1431-1462. Córdoba.

Varol, O. 1989. Paleocene calcareous nannofossil biostratigraphy. In Nannofossils and their applications (Crux, J.A.; Van Heck, S.E.; editors). British Micropaleontological Society Series, Ellis Horwood Limited, Chichester: 267-310.

Varol, O. 1999. Palaeogene. In Calcareous Nannofossil Biostratigraphy (Bown, P.R.; editor). British Micropalaeontological Society Publications Series, Kluwer Academic Publishers, edition 2: 200-224. London.

Manuscript received: July 26, 2011; revised/accepted: April 12, 2012; available online: July 25, 2012. 


\section{APPENDIX}

\section{List of taxa identified in this study}

Braarudosphaera bigelowii (Gran and Braarud, 1935) Deflandre, 1947

Chiasmolithus bidens (Bramlette and Sullivan, 1961) Hay and Mohler, 1967

Chiasmolithus consuetus (Bramlette and Sullivan, 1961) Hay and Mohler, 1967

Chiasmolithus eograndis Perch-Nielsen, 1971

Chiasmolithus expansus (Bramlette and Sullivan, 1961) Gartner, 1970

Chiasmolithus grandis (Bramlette and Riedel, 1954) Radomski, 1968

Chiasmolithus modestus Perch-Nielsen, 1971

Chiasmolithus oamaruensis (Deflandre, 1954) Hay et al., 1966

Chiasmolithus solitus (Bramlette and Sullivan, 1961) Locker, 1968

Coccolithus formosus (Kamptner, 1963) Wise, 1973

Coccolithus pelagicus (Wallich, 1871) Schiller, 1930

Cruciplacolithus edwardsii Romein, 1979

Cruciplacolithus primus Perch-Nielsen, 1977

Cruciplacolithus staurion (Bramlette and Sullivan, 1961) Gartner, 1971

Cruciplacolithus tenuis (Stradner, 1961) Hay and Mohler in Hay et al., 1967

Cyclicargolithus floridanus (Roth and Hay in Hay et al., 1967) Bukry, 1971

Cyclicargolithus luminis (Sullivan, 1965) Bukry, 1971

Discoaster deflandrei Bramlette and Riedel, 1954

Helicosphaera ethologa Bown, 2005

Helicosphaera lophota Bramlette and Sullivan, 1961

Holodiscolithus solidus (Deflandre in Deflandre and Fert, 1954) Roth, 1970

Hornibrookina teuriensis Edwards, 1973

Hornibrookina weimerae Self-Trail, 2011

Lanternithus minutus Stradner, 1962

Markalius apertus Perch-Nielsen, 1979

Markalius inversus (Deflandre in Deflandre and Fert, 1954) Bramlette and Martini, 1964

Neochaistozygus chiastus (Bramlette and Sullivan, 1961) Perch-Nielsen, 1971

Neochiastozygus concinnus (Martini, 1961) Perch-Nielsen, 1971

Neococcolithes dubius (Deflandre in Deflandre and Fert, 1954) Black, 1967

Neococcolithes protenus (Bramlette and Sullivan, 1961) Black, 1967

Placozygus sigmoides (Bramlette and Sullivan, 1961) Romein, 1979

Pontosphaera exilis (Bramlette and Sullivan, 1961) Romein, 1979

Pontosphaera multipora (Kamptner, 1948) Roth, 1970

Pontosphaera pulchra (Deflandre in Deflandre and Fert, 1954) Romein, 1979

Praeprinsius dimorphosus (Perch-Nielsen, 1969) Varol and Jakubowsky, 1989

Reticulofenestra bisecta bisecta (Hay et al., 1966) Roth, 1970

Reticulofenestra bisecta filewiczii Wise and Wiegand in Wise, 1983

Reticulofenestra daviesii (Haq, 1968) Haq, 1971

Reticulofenestra dictyoda (Deflandre in Deflandre and Fert, 1954) Stradner in Stradner and Edwards, 1968

Reticulofenestra minuta Roth, 1970

Reticulofenestra oamaruensis (Deflandre in Deflandre and Fert, 1954) Stradner in Haq, 1968

Reticulofenestra reticulata (Gartner and Smith, 1967) Roth and Thierstein, 1972

Reticulofenestra scrippsae (Bukry and Percival, 1971) Roth, 1973

Reticulofenestra umbilica (Levin, 1965) Martini and Ritzkowski, 1968 
Sphenolithus moriformis (Brönnimann and Stradner, 1960) Bramlette and Wilcoxon, 1967 Sullivania danica (Brotzen, 1959) Varol, 1992

Thoracosphaera heimii (Lohmann, 1919) Kamptner, 1941

Thoracosphaera operculata Bramlette and Martini, 1964

Thoracosphaera saxea Stradner, 1961

Toweius africanus (Perch-Nielsen, 1981) Perch-Nielsen, 1984

Toweius callosus Perch-Nielsen, 1971

Toweius eminens (Bramlette and Sullivan, 1961) Perch-Nielsen, 1971

Toweius occultatus (Locker, 1967) Perch-Nielsen, 1971

Toweius rotundus Perch-Nielsen in Perch-Nielsen et al., 1978

Zygrhablithus bijugatus (Deflandre in Deflandre and Fert, 1954) Deflandre, 1959 